\title{
Viktoriia Ishchenko*. Protection of energy investments under the Russia-Ukraine bilateral investment treaty of 1998
}

\author{
Suggested citation:
}

Ishchenko, V. (2018). Protection of energy investments under the Russia-Ukraine bilateral investment treaty of 1998. Lex Portus, no. 1, 33-43. https://doi.org/10.26886/2524101X.1.2018.3

*Viktoriia Ishchenko. Attorney at Law, Leading Legal Counsel at PJSC "Ukrnafta", Member of the Energy, Oil and Gas Committee of Ukrainian Bar Association (3-5, Nestorivskiy trans., Kyiv, Ukraine).

\begin{abstract}
Russian invasion into Ukraine, which resulted in annexation of the Autonomous Republic of Crimea and the City of Sevastopol in 2014, has created a wide range of complex legal issues, in particular those related to protection of investments in the energy sector. A new government established by the Russian Federation in Crimea seized certain assets owned by Ukrainian legal entities on the Crimean Peninsula and further nationalized them without payment of any compensation. The most valuable energy assets in Crimea were among the Russian Federation's chief targets. In response, numerous arbitrations were initiated against the Russian Federation. The pending arbitration proceedings include claims of the leading Ukrainian energy companies. This publication provides information about an effective legal instrument used by Ukrainian companies in energy sector to protect their investments on the territory of the Crimean Peninsula and to arbitrate their claims for compensation of the damages caused due to the Russian Federation's unlawful annexation of Crimea. The relevance of this instrument for the Ukrainian energy companies can be explained by reference to the judgement issued on 20 April 2016 by the Hague District Court which annulled an earlier Yukos award against the Russian Federation, holding that the Energy Charter Treaty, the only multilateral agreement dealing with the energy sector, had not been ratified by Russia and could not apply in relation to it. In light of the foregoing, claimants had to find an alternative way to make the Russian Federation liable for the unlawful expropriations.
\end{abstract}

The key words: annexation of Crimea, energy resources, Ukraine, Russia, the BIT, investments, ECT, arbitration. 


\section{REFERENCES}

Aeroport Belbek LLC and Mr Kolomoisky $v$ The Russian Federation. PCA Case No. 2015-07. Retrieved from https://pcacases.com/web/sendAttach/1553

Convention on the Recognition and Enforcement of Foreign Arbitral Awards 1958 (The United Nations Commission on International Trade Law). Official site of the The United Nations Commission on International Trade Law. Retrieved from http://www.uncitral.org/pdf/english/texts/arbitration/NY-conv/New-YorkConvention-E.pdf

Dogovor o prinjatii v Rossijskuju Federaciju Respubliki Krym i obrazovanii v sostave Rossijskoj Federacii novyh subektov 2014 (Rossijskaja Federacija i Respublika Krym). Oficial'nye setevye resursy Prezidenta Rossii. [Official Internet Resources of the President of Russia]. Retrieved from http://kremlin.ru/events/president/news/20605 [in Russian].

Everest Estate LLC and others $v$ The Russian Federation. PCA Case No. 2015-36. Retrieved from https://pcacases.com/web/sendAttach/1856

Happ, R., Wuschka, S. (2016). Horror Vacui: Or Why Investment Treaties Should Apply to Illegally Annexed Territories, Journal of International Arbitration, 33, no. 3, 245-268.

JSC Oschadbank $v$ The Russian Federation. Retrieved from http://investmentpolicyhub.unctad.org/ISDS/Details/724

Konstitucija Rossijskoj Federacii 1993 (Vsenarodnoe golosovanie), s uchetom izmenenij, vnesennyh federal'nym konstitucionnym zakonom ot 21 marta 2014 № 6-FKZ [The Constitution of the Russian Federation 1993 (Popular vote), taking into account the changes introduced by the federal constitutional law of March 21, 2014 No. 6-FKZ]. Retrieved from http://konstitucija.ru/1993/13/ [in Russian].

LLC Lugzor and others $v$ The Russian Federation. PCA Case No. 2015-29. Retrieved from https://pcacpa.org/en/cases/124/

PCA press release of 2 May 2016. Retrieved from https://pcacases.com/web/sendAttach/1703

PCA press release of 4 July 2017. Retrieved from https://pcacases.com/web/sendAttach/2184

PCA press release of 19 February 2018. Retrieved from https://pcacases.com/web/sendAttach/2291

PJSC Ukrnafta $v$ The Russian Federation. PCA Case No. 2015-3. Retrieved from https://pcacpa.org/en/cases/121/

Postanovlenie o vnesenii izmenenija v Postanovlenie Gosudarstvennogo Soveta Respubliki Krym ot 30 aprelja 2014 goda № 2085-6/14 "O voprosah upravlenija sobstvennost'ju Respubliki Krym" (Gosudarstvennyj Sovet Respubliki Krym) [Resolution on Amendments to the Resolution of the State Council of the Republic of Crimea of April 30, 2014 No. 2085-6/14 "On the management of the property of the Republic of Crimea" (State Council of the Republic of Crimea)]. Retrieved from http://crimea.gov.ru/app/3854 [in Russian].

Privatbank and Finance Company Finilion LLC $v$ The Russian Federation. Permanent Court of Arbitration (PCA) Case No. 2015-21. Retrieved from https://pcacases.com/web/sendAttach/1619

Publication on the official website of NJSC Naftogaz of Ukraine of 19 October 2016. Retrieved from http://www.naftogaz.com/www/3/nakweben.nsf/0/DC8AA6A56E589FE3C225805100278490?OpenDocumen t\&year=2016\&month=10\&nt=News\&

Putin admits Russian military presence in Ukraine for first time. The Guardian international edition. 17 December 2015. Retrieved from https://www.theguardian.com/world/2015/dec/17/vladimir-putin-admitsrussian-military-presence-ukraine

Stabil LLC and others $v$ The Russian Federation. PCA Case No. 2015-35. Retrieved from https://pcacpa.org/en/cases/122/

The coverage the sixty-eighth plenary meeting of the General Assembly of the United Nations performed by the United Nations. Official site of the United Nations. Retrieved from: https://www.un.org/press/en/2014/ga11493.doc.htm

The Energy Charter Treaty 1994 (United Nations). Retrieved from https://energycharter.org/fileadmin/DocumentsMedia/Legal/ECTC-en.pdf 
The judgement of the Hauge District Court issued on 20 April 2016. Retrieved from https://www.italaw.com/sites/default/files/case-documents/italaw7255.pdf

Uhoda pro zaokhochennia ta vzaiemnyi zakhyst investytsii 1998 (Kabinet Ministriv Ukrainy, Uriad Rosiiskoi Federatsii) [Agreement on encouragement and mutual protection of investments in 1998 (Cabinet of Ministers of Ukraine, Government of the Russian Federation)]. Ofitsiynyy sayt Verkhovnoyi Rady Ukrayiny [The official website of the Verkhovna Rada of Ukraine]. Retrieved from http://zakon2.rada.gov.ua/laws/show/643 101/ [in Ukrainian].

UNCITRAL Arbitration Rules (as revised in 2010). Retrieved from https://www.uncitral.org/pdf/english/texts/arbitration/arb-rules-revised/arb-rules-revised-2010-e.pdf

Vienna Convention of the Law of Treaties 1969 (United Nations). Official site of the The United Nations. Retrieved from https://treaties.un.org/doc/publication/unts/volume\%201155/volume-1155-i-18232-english.pdf

Zakon o ratifikacii Dogovora mezhdu Rossijskoj Federaciej i Respublikoj Krym o prinjatii v Rossijskuju Federaciju Respubliki Krym i obrazovanii v sostave Rossijskoj Federacii novyh subektov 2014 (Gosudarstvennaja Duma Rossijskoj Federacii). [Law on ratification of the Treaty between the Russian Federation and the Republic of Crimea on the admission to the Russian Federation of the Republic of Crimea and the formation of new subjects within the Russian Federation 2014 (The State Duma of Russian Federation)]. Garant.ru. Retrieved from http://base.garant.ru/70618344 [in Russian]. 


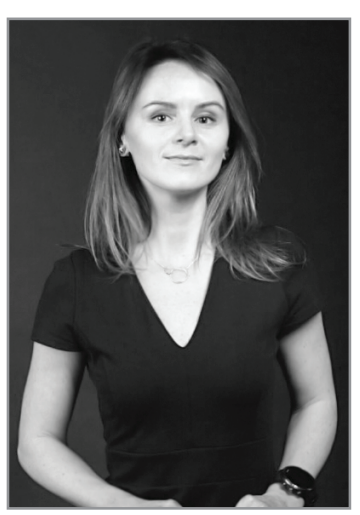

Viktoriia Ishchenko,

Attorney at Law,

Leading Legal Counsel at PJSC "Ukrnafta",

Member of the Energy, Oil and Gas Committee

of Ukrainian Bar Association

(Kyiv, Ukraine)

ORCID: https://orcid.org/0000-0003-1433-8101

UDC 341.6:330.322

DOI 10.26886/2524-101X.1.2018.3

\section{PROTECTION OF ENERGY INVESTMENTS UNDER THE RUSSIA-UKRAINE BILATERAL INVESTMENT TREATY OF 1998}

Russian invasion into Ukraine, which resulted in annexation of the Autonomous Republic of Crimea and the City of Sevastopol in 2014, has created a wide range of complex legal issues, in particular those related to protection of investments in the energy sector. A new government established by the Russian Federation in Crimea seized certain assets owned by Ukrainian legal entities on the Crimean Peninsula and further nationalized them without payment of any compensation. The most valuable energy assets in Crimea were among the Russian Federation's chief targets. In response, numerous arbitrations were initiated against the Russian Federation. The pending arbitration proceedings include claims of the leading Ukrainian energy companies. This publication provides information about an effective legal instrument used by Ukrainian companies in energy sector to protect their investments on the territory of the Crimean Peninsula and to arbitrate their claims for compensation of the damages caused due to the Russian Federation's unlawful annexation of Crimea. The relevance of this instrument for the Ukrainian energy companies can be explained by reference to the judgement issued on 20 April 2016 by the Hague District Court which annulled an earlier Yukos award against the Russian Federation, holding that the Energy Charter Treaty, the only multilateral agreement dealing with the energy sector, had not been ratified by Russia and could not apply in relation to it. In light of the foregoing, claimants had to find an alternative way to make the Russian Federation liable for the unlawful expropriations.

Keywords: annexation of Crimea, energy resources, Ukraine, Russia, the BIT, investments, ECT, arbitration

(C) Ishchenko V., 2018 
Іщенко В. Захист енергетичних інвестицій згідно з російсько-украӥнською двосторонньою інвестиційною угодою 1998 р. - Стаття.

Вторгнення Росії в Україну i, як наслідок, анексія Автономної Республіки Крим та міста Севастополя у 2014 році, створило широкий спектр складних юридичних питань, зокрема пов'язаних із захистом інвестицій в енергетичному секторі. Новий уряд, встановлений Російською Федерацією у Криму, захопив певні активи, що належать українським юридичним особам на Кримському півострові, а пізніше націоналізував їх без виплати будь-якої компенсації. Найбільш цінні енергетичні активи у Криму були серед головних цілей Російської Федерації. У відповідь було порушено безліч арбітражних справ проти Російської Федерації. Поточні арбітражні провадження включають позови провідних українських енергетичних компаній. У цій публікації міститься інформація про ефективний правовий інструмент, що застосовується українськими компаніями енергетичного сектора для захисту своїх інвестицій на території Кримського півострова і для можливості звернення до арбітражу з вимогами про відшкодування шкоди, заподіяної внаслідок незаконної анексії Криму Російською Федерацією. Значення цього інструменту для українських енергетичних компаній можна пояснити рішенням, прийнятим Окружним судом м. Гааги від 20 квітня 2016 року, яким раніше присуджена компенсація на користь ЮКОСа в справі проти Російської Федерації, була скасована у зв'язку з тим, що єдина багатостороння угода в енергетичному секторі - Договір до Енергетичної хартії, виявився нератифікованим Росією і тому не може застосовуватися відносно неї. 3 огляду на вищезазначене, заявникам довелося знайти альтернативний спосіб притягнення Російської Федерації до відповідальності за незаконну експропріацію.

Ключові слова: анексія Криму, енергетичні ресурси, Україна, Росія, угода, інвестиції, ДЕХ, арбітраж.

Ищенко В. Зацита энергетических инвестиций в соответствии с российскоукраинским двусторонним инвестиционным договором 1998 г. - Статья.

Российское вторжение в Украину, которое привело к аннексии Автономной Республики Крым и города Севастополя в 2014 году, создало широкий спектр сложных юридических вопросов, в частности связанных с защитой инвестиций в энергетическом секторе. Новое правительство, созданное Российской Федерацией в Крыму, захватило определенные активы, принадлежащие украинским юридическим лицам на Крымском полуострове, а после национализировало их без выплаты какой-либо компенсации. Наиболее ценные энергетические активы в Крыму были среди главных целей Российской Федерации. В ответ было возбуждено множество арбитражных дел против Российской Федерации. Текущие арбитражные производства включают иски ведущих украинских энергетических компаний. В этой публикации содержится информация об эффективном правовом инструменте, используемом украинскими компаниями энергетического сектора для защиты своих инвестиций на территории Крымского полуострова и для возможности передачи в арбитраж требований о возмеще- 
нии ущерба, причиненного в результате незаконной аннексии Крыма Российской Федерацией. Значение этого инструмента для украинских энергетических компаний можно объяснить решением, принятым Окружным судом г. Гааги от 20 апреля 2016 года, которым ранее присужденная компенсация в пользу ЮКОСа в деле против Российской Федерации, была отменена в связи с тем, что единственное многостороннее соглашение в энергетическом секторе - Договор к Энергетической хартии, оказался нератифицированным Россией и поэтому не может применяться по отношению к ней. В свете вышесказанного, заявителям пришлось найти альтернативный способ привлечения Российской Федерации к ответственности за незаконную экспроприацию.

Ключевые слова: аннексия Крыма, энергетические ресурсы, Украина, Россия, соглашение, инвестиции, ДЭХ, арбитраж.

Russian invasion into Ukraine, which resulted in illegal annexation of the Autonomous Republic of Crimea and the City of Sevastopol in 2014, has created a wide range of complex legal issues related to energy investments' protection. The most valuable energy assets in Crimea were among the Russian Federation's chief targets. How can Ukrainian energy companies make the Russian Federation liable for the measures it took in relation to their assets in Crimea? What legal instruments are of use? Who are "ground breakers" in claiming protections for the damages caused by Russian Federation?

In February 2014, the Russian Federation occupied the Autonomous Republic of Crimea and the City of Sevastopol. The Russian Federation asserted factual control over the Crimean Peninsula through use of force [1], followed by numerous acts, aimed at the establishment of the legal control over the occupied territory. These measures, in particular include: 1) a so-called Crimean referendum simulated on 16 March 2014 on the question of separation of Crimea from Ukraine and its incorporation into the Russian Federation as a federal subject; and 2) the enactment of the Federal Law dated 21 March 2014 "On ratification of the treaty between the Russian Federation and the Republic of Crimea on the acceptance of the Republic of Crimea into the Russian Federation and the formation of new constituent parts within the Russian Federation" (hereinafter - RussianCrimea Annexation Treaty) [2].

Russian invasion into Ukraine, which resulted in annexation of the Autonomous Republic of Crimea and the City of Sevastopol was in violation of international law, the United Nations Charter and Ukraine's Constitution. Ukraine's position is corroborated by 100 other Members States of the United Nations. 
On 27 March 2014, the General Assembly of the United Nations at its at sixty-eighth plenary meeting adopted a resolution titled "Territorial integrity of Ukraine", calling on States, international organizations and specialized agencies not to recognize any change in the status of Crimea or the Black Sea port city of Sevastopol, and to refrain from actions or dealings that might be interpreted as such. Also by the text, the Assembly called on States to "desist and refrain" from actions aimed at disrupting Ukraine's national unity and territorial integrity, including by modifying its borders through the threat or use of force. It urged all parties immediately to pursue a peaceful resolution of the situation through direct political dialogue, to exercise restraint, and to refrain from unilateral actions and inflammatory rhetoric that could raise tensions [3].

Irrespective of the dispute over the legality of the annexation of the Autonomous Republic of Crimea and the City of Sevastopol and the call of international community to refrain from actions aimed at disrupting Ukraine's national unity and territorial integrity, the Russian Federation has assumed factual and jurisdictional control over the territory of Crimea since 21 March 2014, the date when the Russian-Crimea Annexation Treaty was ratified by the Federal Assembly [4]. By virtue of this law, the Autonomous Republic of Crimea and the City of Sevastopol were divided into two territorial units with their own governments, authorized to enact laws and enforce them on behalf of the Russian Federation, as its federal subjects.

On 30 April 2014, the so-called State Council of the Republic of Crimea enacted Decree No.2085-6/14 “On certain questions of assets' management of the Republic of Crimea" [5]. The Decree was later amended to include assets owned by Ukrainian legal entities. Those assets were thus transferred to the Republic of Crimea (nationalized), without payment of any compensation.

In response, numerous investment arbitrations were initiated against the Russian Federation. The pending arbitration proceedings (the list is not exhaustive) include:

1) JSC Oschadbank $v$ the Russian Federation, whereby the claimant contends that the Russian Federation seized a branch of Oschadbank in Crimea [6];

2) Privatbank and Finance Company Finilion LLC v the Russian Federation, whereby the claimants assert that the Russian Federation took, as of February 2014, measures that prevented them from operating their banking business in Crimea [7]; 
3) Aeroport Belbek LLC and Mr Kolomoisky v the Russian Federation, whereby claimants contend that the Russian Federation took measures, as of February 2014 that deprived the claimants of their property, contractual and other rights to operate a passenger terminal for commercial flights at the Belbek International Airport in Crimea [8];

4) Everest Estate LLC and others $v$ the Russian Federation, whereby Everest Estate LLC and others contend that, as of August 2014, the Russian Federation interfered and ultimately expropriated their investments in real estate located in Crimea [9];

5) Lugzor LLC and others $v$ the Russian Federation, whereby Limited Liability Company Lugzor and others contend that the Russian Federation interfered and ultimately expropriated their investments in real estate located in Crimea [10].

Claimants in certain of those cases potentially could claim protection under the Energy Charter Treaty [11]. Those cases are:

1) NJSC Naftogaz of Ukraine (Ukraine) and others v. the Russian Federation;

2) Stabil LLC and others $v$ the Russian Federation [12];

3) PJSC Ukrnafta $v$ the Russian Federation [13].

According to the information provided on the official website of the Permanent Court of Arbitration (hereinafter - the PCA) on 3 June 2015, two arbitral proceedings were commenced by PJSC "Ukrnafta" and by Stabil LLC and ten other companies against the Russian Federation claiming that, as of April 2014, the Russian Federation interfered and ultimately expropriated their investments in petrol stations located in Crimea [14].

Although, the PCA has not published yet the press release regarding the case between NJSC Naftogaz of Ukraine (Ukraine) and others $v$. the Russian Federation, the official website of Naftogaz contains information that: "the most valuable energy assets in Crimea were among the Russian Federation's chief targets. The Russian Federation's actions against NJSC Naftogaz of Ukraine involved taking steps to formally nationalize Naftogaz's oil and gas assets in Crimea, including by sending armed men to commandeer Naftogaz's drilling platforms, and ultimately transferring almost all of Naftogaz's Crimea-based assets to a Russian state-owned company" [15]. In addition, according to the PCA case registry the arbitrations commenced by NJSC Naftogaz of Ukraine, PJSC "Ukrnafta" and Stabil LLC against the Russian Federation are marked as related to Oil and gas or Electricity sector. 
The arbitration proceedings listed above are of particular interest in light of the judgement issued on 20 April 2016 by the Hague District Court which annulled an earlier Yukos award against the Russian Federation, holding that the Energy Charter Treaty had not been ratified by Russia and could not apply [16].

In view of the foregoing, it appears that Ukrainian companies engaged in economic activity in the energy sector are currently prevented from claiming protections offered by the ECT in relation to the Russian Federation's unlawful expropriation of the assets in Crimea. However, the judgement of the Hauge District Court issued on 20 April 2016 annulling the earlier award made in favour of the majority shareholders of Yukos is not final.

While the ECT, which is the only multilateral agreement dealing with inter-governmental cooperation in the energy sector does not apply in relation to the Russian Federation, and consequently a special protection provided therein is not applicable, the claimants, involved in energy sector are entitled to claim the benefit of the various protections given by other agreements, which were duly ratified by the Russian Federation. In particular, pursuant to the Agreement between the Government of the Russian Federation and the Cabinet of Ministers of Ukraine on the Encouragement and Mutual Protection of Investments dated 27 November 1998 (hereinafter - the "Treaty" or "BIT") [17] an energy company is entitled to seek compensatory relief from the Russian Federation for the breach of the following provisions of the Treaty: Article 2 (2) which provides that each Contracting Party guarantees in accordance with its legislation, the full and unconditional legal protection of investments by investors of the other Contracting Party and Article 5 which refers to prohibition of the investments' nationalization, expropriation or equivalent measures.

According to Article 9 of the BIT, a claimant can demand arbitration to be held either under the Stockholm Chamber of Commerce Arbitration Rules (Unless the parties agreed otherwise), or the Arbitration Regulations of the United Nations Commission for International Trade Law (hereinafter - UNCITRAL). The dispute should be referred respectively: either to the Arbitration Institute of the Stockholm Chamber of Commerce, or the "ad hoc" arbitration tribunal under Article 6 of the 1976 UNCITRAL [18]. Article 1.2 of UNCITRAL, as revised in 2010, provides that the parties to an arbitration agreement concluded after 15 August 2010 shall be presumed to have referred to the Rules in effect on the date of commencement of the arbitration, unless the parties have agreed to apply a particular ver- 
sion of the Rules. That presumption does not apply where the arbitration agreement has been concluded by accepting after 15 August 2010 an offer made before that date.

Taking into account the amount of pending arbitrations against the Russian Federation in regard to the consequences of its actions in the Autonomous Republic of Crimea and the city of Sevastopol which are administered by the PCA, it appears that the second option, namely to file claims with the "ad hoc" arbitration tribunal is more preferable to Ukrainian companies.

The third option of the dispute resolution provided by Article 9(1) (a) of the BIT is to refer a dispute to a competent court or arbitazh court of the Contracting Party on whose territory the investment was made.

Taking into consideration that Article 9 of the BIT is not an arbitration agreement but an offer to arbitrate, a claimant should send a notice of dispute to the pertinent Contracting Party six months before filing a claim. This notice should include acceptance of the offer to arbitrate and the choice of one of the options provided by Article 9 of the BIT. Also, According to Article 2 of the New York Convention of 1958 "On the Recognition and Enforcement of Foreign Arbitral Awards" [19] each Contracting State shall recognize an agreement in writing under which the parties undertake to submit to arbitration all or any differences which have arisen or which may arise between them in respect of a defined legal relationship, whether contractual or not, concerning a subject matter capable of settlement by arbitration. The term "agreement in writing" shall include an arbitral clause in a contract or an arbitration agreement, signed by the parties or contained in an exchange of letters or telegrams.

Along with the procedural requirement contained in Article 9 of the BIT, namely that of a six months "cooling period" (Article 9 (2) of the BIT) between the service of the notice of the dispute and commencement of arbitration, the said article provides conditions to arbitrate disputes against the Russian Federation under the BIT. Namely, 1) there must be a dispute between a Contracting Party to the BIT and an investor of the other Contracting Party to the BIT; 2) the dispute must arise in connection with an investment (Article 9 (1) of the BIT).

Article 1(2) (b) of the BIT defines "Investor of a Contracting Party" as "any legal entity established according to the laws of the given Contracting Party, on the condition that the said legal entity is capable under the laws of its respective Contracting Party to make investments on the territory of the other Contracting Party". 
Whereas a company engaged in economic activity in energy sector is a legal entity incorporated in Ukraine and its investments in the Autonomous Republic of Crimea and the city of Sevastopol were lawful under the laws of Ukraine when they were made, it is assumed that such claimant qualifies as an investor for the purposes of Article 1(2) (b) of the BIT.

Article 1(1) of the BIT defines "Investments" as follows:

"All kinds of material and intellectual property which are contributed [are made] [ukr. - "шоо вкладаються"/rus. - «которые вкладываются» ] by an investor of one Contracting Party on the territory of the other Contracting Party in accordance with the latter's laws, including: a) tangible and intangible property, as well as the associated property rights; b) cash, as well as securities, commitments, contributions and other forms of participation; c)intellectual property rights, including copyrights and related rights, trademarks, rights to inventions, industrial samples, models, engineering processes and know-how; d) rights to engage in commercial activity, including rights to the exploration, development and exploitation of natural resources."

Based on the provisions of Article 1(1) (a) and Article 1(1) (d) of the BIT which contain definition of the term "investment", energy resources and rights to operate the respective activity are subject to protection under the BIT and qualify as an investment for the purposes of this Treaty.

However, the definition of "investment" in Article 1(1) of the BIT contains two additional requirements, which must be met to invoke protection under the Treaty, namely an assets must be made by an investor of one Contracting Party in the territory of the other Contracting Party.

In terms of territorial scope of application of the BIT, reference is made to Article 1(4) of the Treaty, whereby the term "territory" denotes the territory of the Russian Federation or the territory of Ukraine as well as their respective exclusive economic zone and the continental shelf, defined in accordance with international law. Taking into account, that the Russian Federation established factual control over the Crimea and provided in its Constitution (Art. 65) that the Republic of Crimea and the Federal City of Sevastopol are constituent parts of the Russian Federation [20], it is assumed that the Autonomous Republic of Crimea and the City of Sevastopol qualify for the term "territory of the Russian Federation" under Article 1 (4) of the BIT and for the purposes of the Treaty only.

According to Article 29 of the Vienna Convention of the Law of Treaties of 23 May 1969 (hereinafter - Vienna Convention 1969) [21], 
unless a different intention appears from the treaty or is otherwise established, a treaty is binding upon each party in respect of its entire territory. The detailed analysis of territorial application of investment treaties, as well as interpretation of the term "entire territory" under Article 29 of the Vienna Convention 1969 was performed in the article "Horror Vacui: Or Why Investment Treaties Should Apply to Illegally Annexed Territories" published in Journal of International Arbitration [22]. The authors of the said article came to the following conclusion:

"Although not explicitly stated, this provision [Article 29 of the Vienna Convention 1969] also entails the so-called moving treaty frontiers rule. According to this concept, which also possesses a customary international law character, the application of a state's treaties is automatically extended to newly acquired territory from the point of the acquisition onwards. The wording 'its entire territory' must therefore be understood 'as "its entire territory at any given time".

In view of the foregoing, the parties' rights and obligations under the BIT extend to entire territory over which a State asserted factual and jurisdictional control, and therefore, assets of the Ukrainian companies, which were expropriated after the annexation of Autonomous Republic of Crimea and the city of Sevastopol by the Russian Federation are subject to protection under the BIT.

In terms of temporal application of the Treaty, Article 12 of the BIT reads:

"The Treaty [the BIT] will apply to all investments made by investors of one Contracting Party in the territory of the other Contracting Party, on or after January 1, 1992."

In this regard, it is worthy of note, that while the BIT was signed on 27 November 1998 and entered into force on 27 January 2000, Article 12 of the said Treaty covers investments which were made on or after 1 January 1992, id est before or after the BIT's entry into force. Except the condition that the investment must be made "on or after 1 January 1992", the BIT set out no additional requirements or restrictions regarding the time of the investment.

In view of the foregoing, Ukrainian energy companies which invested energy resources and/or the respective rights in the territory of Autonomous Republic of Crimea and the city of Sevastopol, on or after 1 January 1992, are entitled to protection provided by the BIT.

Although in Stabil LLC and others $v$ the Russian Federation, PJSC Ukrnafta $v$ the Russian Federation, the Russian Federation states that it 
does not recognize the jurisdiction of the tribunal [23], on 26 June 2017, in the two above-referenced matters, the arbitral tribunal addressed jurisdictional issues in a preliminary procedure and issued its unanimous Awards on Jurisdiction. It appears that the arbitral tribunal will proceed to the hearing on merits of the disputes, which means that both companies satisfied jurisdictional requirements set out in the BIT [24]. Consequently, Ukrainian energy companies may successfully protect their assets, property and rights related to the economic activity in energy sector as investments under the BIT.

But what is more important, the Agreement concluded between the Government of the Russian Federation and the Cabinet of Ministers of Ukraine on the Encouragement and Mutual Protection of Investments of 27 November 1998 does not imply that the arbitral tribunals must consider the dispute between Ukraine and the Russian Federation over the legality of annexation of the territory of Autonomous Republic of Crimea and the city of Sevastopol in 2014. The task of the arbitral tribunal in the disputes under the BIT is to determine, whether the investments of Ukrainian investors in Crimea are covered by the protection provided by the Treaty. This undoubtedly makes the BIT an effective legal instrument for investors' rights' protection, including those who are engaged in energy sector.

\section{BIBLIOGRAPHY}

1. Putin admits Russian military presence in Ukraine for first time. The Guardian international edition. 17 December 2015 URL: https:/www.theguardian.com/ world/2015/dec/17/vladimir-putin-admits-russian-military-presence-ukraine

2. Договор между Российской Федерацией и Республикой Крым о принятии в Российскую Федерацию Республики Крым и образовании в составе Российской Федерации новых субъектов от 18 марта 2014 URL: http:/kremlin.ru/events/ president/news/20605

3. The coverage the sixty-eighth plenary meeting of the General Assembly of the United Nations performed by the United Nations. URL: https://www.un.org/press/en/2014/ ga11493.doc.htm

4. О ратификации Договора между Российской Федерацией и Республикой Крым о принятии в Российскую Федерацию Республики Крым и образовании в составе Российской Федерации новых субъектов: Федеральный закон от 21 марта 2014 г. № 36-Ф3. URL: http://base.garant.ru/70618344

5. О внесении изменения в Постановление Государственного Совета Республики Крым от 30 апреля 2014 года № 2085-6/14 «О вопросах управления собственностью Республики Крым»: Постановление ГС PK. URL: http://crimea.gov.ru/app/3854

6. JSC Oschadbank v The Russian Federation. URL: http://investmentpolicyhub.unctad. org/ISDS/Details/724 
7. Privatbank and Finance Company Finilion LLC v The Russian Federation. Permanent Court of Arbitration (PCA) Case No. 2015-21. URL: https://pcacases.com/web/ sendAttach/1619

8. Aeroport Belbek LLC and Mr Kolomoisky v The Russian Federation. PCA Case No. 2015-07. URL: https://pcacases.com/web/sendAttach/1553

9. Everest Estate LLC and others v The Russian Federation. PCA Case No.2015-36. URL: https://pcacases.com/web/sendAttach/1856

10. LLC Lugzor and others $v$ The Russian Federation. PCA Case No. 2015-29. URL: https://pca-cpa.org/en/cases/124/

11. The Energy Charter Treaty of December 1994. Entered into force on 16 April 1998. URL: https://energycharter.org/fileadmin/DocumentsMedia/Legal/ECTC-en.pdf

12. Stabil LLC and others $v$ The Russian Federation. PCA Case No. 2015-35. URL: https://pca-cpa.org/en/cases/122/

13. PJSC Ukrnafta $v$ The Russian Federation. PCA Case No.2015-3. URL: https://pca-cpa.org/en/cases/121/

14. PCA press release of 2 May 2016. URL: https://pcacases.com/web/sendAttach/1703

15. Publication on the official website of NJSC Naftogaz of Ukraine of 19 October 2016 URL: http://www.naftogaz.com/www/3/nakweben.nsf/0/DC8AA6A56E589FE3C225 805100278490 ? OpenDocument \&year $=2016 \&$ month $=10 \& n t=$ News \&

16. The judgement of the Hauge District Court issued on 20 April 2016. URL: https://www.italaw.com/sites/default/files/case-documents/italaw7255.pdf

17. Угода між Кабінетом Міністрів України і Урядом Російської Федерації про заохочення та взаємний захист інвестицій від 27 листопада 1998 p. URL: http://zakon2.rada.gov.ua/laws/show/643_101/

18. UNCITRAL Arbitration Rules (as revised in 2010). URL: https://www.uncitral.org/ pdf/english/texts/arbitration/arb-rules-revised/arb-rules-revised-2010-e.pdf

19. Convention on the Recognition and Enforcement of Foreign Arbitral Awards. New York, 1958. URL: http:/www.uncitral.org/pdf/english/texts/arbitration/NY-conv/ New-York-Convention-E.pdf

20. Конституция Российской Федерации. Принята всенародным голосованием 12 декабря 1993 г. С учетом изменений, внесенных федеральным конституционным законом от 21 марта 2014 г. № 6-ФК3. URL: http://konstitucija.ru/1993/13/

21. Vienna Convention of the Law of Treaties of 23 May 1969. URL: https:// treaties.un.org/doc/publication/unts/volume\%201155/volume-1155-i-18232-english.pdf

22. Horror Vacui: Or Why Investment Treaties Should Apply to Illegally Annexed Territories, by Happ, Richard \& Wuschka, Sebastian; Journal of International Arbitration 33, no. 3 (2016): 245-268 c 2016 Kluwer Law International BV, the Netherlands.

23. PCA press release of 4 July 2017. URL: https://pcacases.com/web/sendAttach/2184

24. PCA press release of 19 February 2018. URL: https://pcacases.com/web/ sendAttach/2291

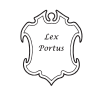

